Original Article

\title{
A1166C Polymorphism of the Angiotensin II Type 1 Receptor Gene and Essential Hypertension in Han, Tibetan and Yi Populations
}

\author{
Ying LIU, Ciren ZHUOMA* , Guangliang SHAN, Chaoying CUI ${ }^{* *}$, Shuqin HOU ***, \\ Weijun QIN* ${ }^{*}$, Dan CAI ${ }^{* *}$, Luobu GESANG ${ }^{*}$, Zhansen XIAO ${ }^{* * *}$, Zhaxi PINGCUO* \\ Huaqing ZHENG ${ }^{* * *}$, Zhenglai WU, Wenyu ZHOU, and Changchun QIU
}

\begin{abstract}
Our aim was to clarify whether substitution of cytosine for adenine at position 1166 (A1166C) polymorphism of the angiotensin II type 1 receptor $\left(A T_{1} R\right)$ gene is associated with susceptibility to essential hypertension in Han, Tibetan and Yi populations in China. This study involved 302 normotensive and 446 hypertensive subjects. The polymorphism was detected by polymelase chain reaction of genomic DNA and restriction fragment length polymorphism (PCR-RFLP) in genomic DNA. The data were analyzed by analysis of covariance (ANCOVA), $X^{2}$ test, and multiple logistic regression. In normotensive controls, the A1166 allele frequencies were $0.979,0.939$ and 0.965 in Han, Tibetan and Yi participants, respectively. There was no significant intergroup variation in frequency of the allele in normotensives $\left(X^{2}=4.166, p=0.125\right)$. The frequency of the $\mathbf{A 1 1 6 6}$ allele was significantly higher in Tibetan male hypertensives than that in normotensives $\left(X^{2}=11.46\right.$, $p=0.001$ ). There was no significant difference in A1166C genotype distribution and allele frequency between normotensives and hypertensives either in the Han $(p=0.465)$ or $Y i(p=0.357)$ populations. Body mass index in the Han and Yi populations $(p=0.0001)$, age in the Tibetan and Yi populations $(p=0.0001)$, and AA genotype in the Tibetan male population $(p=0.0034)$ all were independent risk factors for hypertension. Diastolic blood pressure levels were significantly higher in Tibetan male subjects with the AA genotype than in those with the AC + CC genotype $(p=0.0040)$. We concluded that the A1166 allele is very common in Han, Tibetan and Yi populations, approximately 1.35-fold more common than in Caucasians. The A1166 allele of the $A T_{1} R$ gene may be a predisposing factor for essential hypertension in Tibetan males. A1166C polymorphism of the $A T_{1} R$ gene is probably not involved in the pathogenesis of essential hypertension in Han or Yi populations. (Hypertens Res 2002; 25: 515-521)
\end{abstract}

Key Words: angiotensin II type 1 receptor, A1166C polymorphism, essential hypertension, Han, Tibetan and Yi populations

From the National Laboratory of Medical Molecular Biology, Institute of Basic Medical Sciences, Chinese Academy of Medical Sciences, Peking Union Medical College, Beijing, P.R. China, ${ }^{*}$ People's Hospital of the Tibet Autonomous Region, Lhasa, Tibet Autonomous Region, P.R. China, ${ }^{* *}$ Tibet Medical College, Lhasa, Tibet Autonomous Region, P.R. China, and ${ }^{* * *}$ the First Hospital of Fangshan, Beijing, P.R. China.

This work was supported by grants from the China Medical Board of New York, Inc. (Grant No. 96-657) and the National Natural Sciences Foundation of China (Grant Nos. 39760067 and 39870687).

Address for Reprints: Changchun Qiu, Prof., National Laboratory of Medical Molecular Biology, Institute of Basic Medical Sciences, Chinese Academy of Medical Sciences, Peking Union Medical College, 5 Dong Dan San Tiao, Beijing 100005, P.R. China. E-mail: liuyingpumc@yahoo. com

Received November 26, 2001; Accepted in revised form March 15, 2002. 


\section{Introduction}

The renin-angiotensin system plays an important role in regulation of blood pressure and electrolyte homeostasis. Angiotensin II, the major biologically active product of the system, exerts its effects via two structurally distinct receptor subtypes: angiotensin II type 1 receptor $\left(\mathrm{AT}_{1} \mathrm{R}\right)$ and angiotensin II type 2 receptor (1). The human $\mathrm{AT}_{1} \mathrm{R}$ gene, which mediates the major cardiovascular effects of angiotensin II, was cloned in 1992 (2) and was present as a single-copy gene on human chromosome $3 q$ 21-25. AT 1 R may be an important target for control of angiotensin II-dependent hypertension, as supported by the results of three studies. First, $\mathrm{AT}_{1} \mathrm{R}$ antagonists were shown to be effective antihypertensive agents (3). Second, a genome-wide scan suggested that the $\mathrm{AT}_{1} \mathrm{R}$ locus is the most significant contributor to hypertension in Finnish populations (4). Third, polymorphisms of the $\mathrm{AT}_{1} \mathrm{R}$ gene have been associated with hypertension (5). Although substitution of cytosine for adenine at position 1166 (A1166C) in the $\mathrm{AT}_{1} \mathrm{R}$ gene was associated with susceptibility to essential hypertension in French and Finnish populations $(5,6)$, this finding was not confirmed in other ethnic groups $(7,8)$, and thus these differences may be due to an ethnic variation. Recently, Paillard et al. (9) found that $\mathrm{AT}_{1} \mathrm{R}$ sites on platelets are of limited density and that there is no effect of the genotype on receptor number or affinity. No data has been reported thus far on the possible influence of $\mathrm{A} 1166 \mathrm{C}$ polymorphism of the $\mathrm{AT}_{1} \mathrm{R}$ gene on blood pressure in Chinese.

Essential hypertension, which is frequently associated with low levels of awareness, treatment and control of the disease, is a major public health problem in China (10). Epidemiological studies indicate that the prevalence rates of essential hypertension vary markedly among the various ethnicities in China $(11,12)$. For example, the Yi ethnic group has the lowest prevalence of hypertension in China $(0.22 \%-3.0 \%)$, whereas Tibetans have the highest in China (17.8\%) (13). Three genetically distinct Chinese populations "the Han, Tibetan and Yi ethnic groups" were described in 1998 (14). In the present study, we investigated the distribution of the genotypes and alleles of A1166C polymorphism of the $\mathrm{AT}_{1} \mathrm{R}$ gene in Han, Tibetan and Yi populations in China, examined the association between the polymorphism and susceptibility to essential hypertension and evaluated independent risk factors for hypertension in Han, Tibetan and Yi populations.

\section{Methods}

\section{Subjects}

The study was approved by the ethical committee of our institution, and the recruited subjects gave their informed consent for the genetic analysis. All subjects were recruited ran- domly from outpatient clinics in Fangshan County of Beijing, in Lhasa of the Tibet Autonomous Region and in the Liangshan Yi Autonomous Prefecture of Sichuan Province. A structured questionnaire was used for data collection on demographic variables, medical history of hypertension and lifestyles. The study group comprised 302 normotensive controls and 446 hypertensive patients. Blood pressure was measured in the right upper arm of subjects after they had sat for at least 30 min using a calibrated mercury sphygmomanometer, and all blood pressure values were taken as the average of three readings. Hypertension subjects were defined as those having a systolic blood pressure (SBP) of 140 $\mathrm{mmHg}$ or greater or a diastolic blood pressure (DBP) of 90 $\mathrm{mmHg}$ or greater. Few of the subjects had previously received antihypertensive agents. All the hypertensive patients were required to be free of secondary hypertension or diabetes mellitus, and to have been diagnosed with hypertension before the age of 60 years. Normotensive subjects were selected from the same population as the hypertensive participants, and had an SBP of less than $140 \mathrm{mmHg}$ and a DBP of less than $90 \mathrm{mmHg}$, and no history of essential hypertension in their first-degree relatives. The sex, age, SBP, DBP and body mass index (BMI) of the subjects are summarized in Table 1.

\section{Analysis of Genomic DNA}

Peripheral blood leukocytes were digested with proteinase $\mathrm{K}$ and then genomic DNA was extracted using phenol and chloroform, followed by ethanol precipitation.

A1166C polymorphism in the 3 untranslated region of the $\mathrm{AT}_{1} \mathrm{R}$ gene was detected by polymerase chain reaction of genomic DNA and restriction fragment length polymorphism (PCR-RFLP) as described by Wang et al. with some modifications (15). The sequence of the sense primer was 5'-ATA ATG TAA GCT CAT CCA CCA AGA AG-3', and that of the antisense primer was 5'-TCT CCT TCA ATT CTG AAA AGT ACT TAA-3'. About 100 ng of genomic DNA were amplified in a total volume of $25 \mu \mathrm{l}$ containing $25 \mathrm{mmol} / \mathrm{l}$ Tris- $\mathrm{HCl}\left(\mathrm{pH}=8.3\right.$ at $\left.25^{\circ} \mathrm{C}\right), 25 \mathrm{mmol} / \mathrm{l} \mathrm{KCl}, 3 \mathrm{mmol} / \mathrm{l}$ $\mathrm{MgCl}_{2}, 5 \%$ formamide, $4 \mathrm{pmol}$ for each primer, $80 \mu \mathrm{mol} / \mathrm{l}$ for each deoxynucleotide trisphosphate, and 0.50 units of DNA polymerase (Biotechnology Center FORWARD GROUP Ltd., Shanghai, P.R. China). PCR amplification was carried out in a PTC-200 MJ Research Peltier Thermal Cycler (Perkin-Elmer Corp., Foster City, USA) and followed by an initial denaturation at $94^{\circ} \mathrm{C}$ for $3 \mathrm{~min}$. This was followed by 30 cycles of denaturation at $94^{\circ} \mathrm{C}$ for $45 \mathrm{~s}$, annealing at $50^{\circ} \mathrm{C}$ for $45 \mathrm{~s}$, and extension at $72^{\circ} \mathrm{C}$ for $45 \mathrm{~s}$ with a final extension at $72^{\circ} \mathrm{C}$ for $5 \mathrm{~min}$. Ten microliters of unpurified PCR product was diluted to $20 \mu \mathrm{l}$ in a recommended buffer containing 10 units of Bfr I enzyme (Boehringer Mannheim $\mathrm{GmbH}$, Mannheim, Germany) and incubated at $37^{\circ} \mathrm{C}$ for $5 \mathrm{~h}$. The digestion products were separated on $3 \%$ agarose gel and visualized directly under UV lighting with ethidium bro- 
Table 1. Main Characteristics of Participants by Population

\begin{tabular}{|c|c|c|c|c|c|c|}
\hline Group & $n$ & Male/Female & Age (years) & BMI $\left(\mathrm{kg} / \mathrm{m}^{2}\right)$ & $\mathrm{SBP}(\mathrm{mmHg})$ & $\mathrm{DBP}(\mathrm{mmHg})$ \\
\hline Han & 239 & & & & & \\
\hline NT & 72 & $45 / 27$ & $50.0 \pm 10.6$ & $22.8 \pm 2.3$ & $118.3 \pm 9.0$ & $76.5 \pm 6.7$ \\
\hline HT & 167 & $85 / 82$ & $48.4 \pm 8.7$ & $26.1 \pm 3.1$ & $161.1 \pm 18.1^{*}$ & $102.7 \pm 9.7^{*}$ \\
\hline Tibetan & 330 & & & & & \\
\hline NT & 115 & $59 / 56$ & $44.1 \pm 11.2$ & $24.9 \pm 3.0$ & $114.3 \pm 11.6$ & $75.8 \pm 7.5$ \\
\hline HT & 215 & $120 / 95$ & $53.6 \pm 12.2$ & $23.6 \pm 3.5$ & $160.6 \pm 31.0^{*}$ & $104.9 \pm 13.7^{*}$ \\
\hline $\mathrm{Yi}$ & 179 & & & & & \\
\hline NT & 115 & $115 / 0$ & $44.3 \pm 5.8$ & $21.1 \pm 2.7$ & $112.8 \pm 8.2$ & $73.3 \pm 6.3$ \\
\hline HT & 64 & $64 / 0$ & $51.2 \pm 11.9$ & $24.8 \pm 3.5$ & $158.8 \pm 28.9^{*}$ & $103.4 \pm 15.3^{*}$ \\
\hline
\end{tabular}

Values are the mean \pm SD unless otherwise indicated. NT, normotensive; HT, hypertensive; BMI, body mass index; SBP, systolic blood pressure; DBP, diastolic blood pressure. ${ }^{*} p=0.001$, for hypertensive $v s$. normotensive subjects by ANCOVA in each ethnic group.

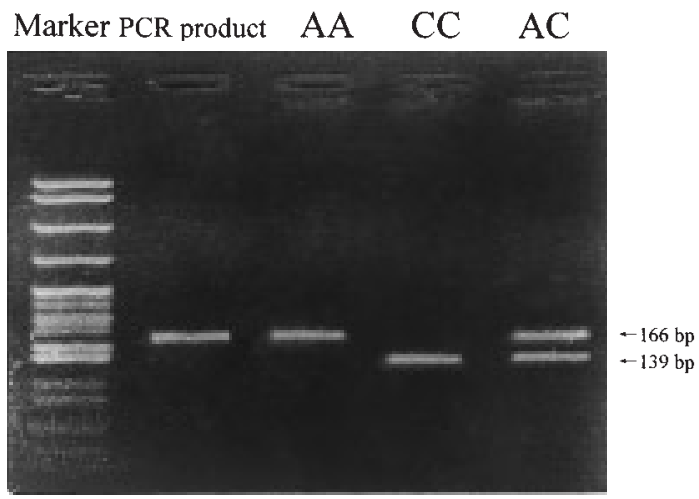

Fig. 1. A1166C polymorphism of the $A T_{1} R$ gene was detect$e d$. The photo shows three genotypes ( $A A, C C$, and $A C)$ seen on an ethidium bromide-stained gel after running Bfr I digestion of PCR-amplified samples. The homozygous (AA) has a band of $166 \mathrm{bp}$, the homozygous (CC) has a band of $139 \mathrm{bp}$, and the heterozygous (AC) has two bands. The first lane shows DNA marker (pBR322-Msp I digest).

mide staining (Fig. 1). The validity of genotyping for the $\mathrm{AA}, \mathrm{AC}$ and $\mathrm{CC}$ genotypes was confirmed by sequencing of the amplified DNA from several subjects using the dideoxymediated chain-termination method.

\section{Statistical Analysis}

All statistical analysis was performed using a statistical software package, SAS version 6.12 (SAS Inst., Inc., Cary, USA). Differences in blood pressure measurements between normotensive and hypertensive subjects in each group were analyzed by analysis of covariance (ANCOVA) adjusted for confounding variables. A genotype was assigned to each subject and allele frequencies were estimated based on the genotype distributions. Because of the very low frequency of the 1166C allele, $\mathrm{CC}$ homozygous subjects were combined with $\mathrm{AC}$ heterozygous subjects in analysis to increase the statistical power. A $\chi^{2}$ test was used to assess the goodnessof-fit between the observed allele frequencies and the expected ones by Hardy-Weinberg equilibrium and to evaluate the difference in genotype distribution between normotensive and hypertensive subjects. Multiple logistic regression analysis was used to assess the relationship between hypertension and A1166C genotypes, with adjustment for the effects of other predicted variables. The odds ratio and its $95 \%$ confidence interval (CI) were calculated for each risk of hypertension. Differences in blood pressure levels among the subjects with different genotypes were analyzed by ANCOVA, and adjusted for sex, age and BMI. Values of $p<0.05$ were considered to indicate statistical significance.

\section{Results}

\section{Characteristics of the Study Subjects}

The distributions of sex, age, BMI, SBP and DBP for the Han, Tibetan and Yi populations are summarized in Table 1. Within each population, there were significant differences in both SBP and DBP between normotensive and hypertensive subjects after adjustment for sex, age, and BMI $(p=0.001)$. No other significant intragroup differences were found.

\section{Genotype Distributions and Allele Frequencies}

The genotype distributions and allele frequencies of the A1166C polymorphism in normotensive and hypertensive subjects of the Han, Tibetan and Yi populations are shown in Table 2.

The distributions of genotype frequencies in normotensive and hypertensive subjects showed that their alleles frequencies were coincident with Hardy-Weinberg equilibrium for all three populations. The homozygous CC genotype was not observed in the Tibetan or Yi populations or in Han normotensives. For normotensive controls, the A1166 allele frequencies of the $\mathrm{AT}_{1} \mathrm{R}$ gene were $0.979,0.939$ and 0.965 in 
Table 2. Genotype Distribution and Allele Frequencies between Normotensive and Hypertensive Subjects

\begin{tabular}{|c|c|c|c|c|c|c|c|}
\hline & \multirow{2}{*}{$\begin{array}{c}n \\
748\end{array}$} & \multicolumn{2}{|c|}{ Genotypes (\%) } & \multicolumn{2}{|c|}{ Alleles } & \multicolumn{2}{|c|}{ Total alleles on chromosomes } \\
\hline & & AA & $\mathrm{AC}+\mathrm{CC}$ & $\mathrm{A}$ & $\mathrm{C}$ & $\mathrm{A}$ & $\mathrm{C}$ \\
\hline Han & 239 & & & & & & \\
\hline NT & 72 & $69(95.8)$ & $3(4.2)$ & 0.979 & 0.021 & 141 & 3 \\
\hline HT & 167 & $156(93.4)$ & $11(6.6)$ & 0.967 & 0.033 & 323 & 11 \\
\hline$\chi^{2}$ & & & & & & & \\
\hline$p$ & & & & & & & \\
\hline Tibetan & 330 & & & & & & \\
\hline NT & 115 & $101(87.8)$ & $14(12.2)$ & 0.939 & 0.061 & 216 & 14 \\
\hline HT & 215 & $207(96.3)$ & $8(3.7)$ & 0.981 & 0.019 & 422 & 8 \\
\hline$\chi^{2}$ & & & & & & & \\
\hline$p$ & & & & & & & \\
\hline $\mathrm{Yi}$ & 179 & & & & & & \\
\hline NT & 115 & $107(93.0)$ & $8(7.0)$ & 0.965 & 0.035 & 222 & 8 \\
\hline HT & 64 & $57(89.1)$ & $7(10.9)$ & 0.945 & 0.055 & 121 & 7 \\
\hline$\chi^{2}$ & & & & & & & \\
\hline$p$ & & & & & & & \\
\hline
\end{tabular}

$n$, number.

Table 3. Genotype Distribution and Allele Frequencies between Normotensive and Hypertensive Tibetan Subjects in Tibetans by Sex

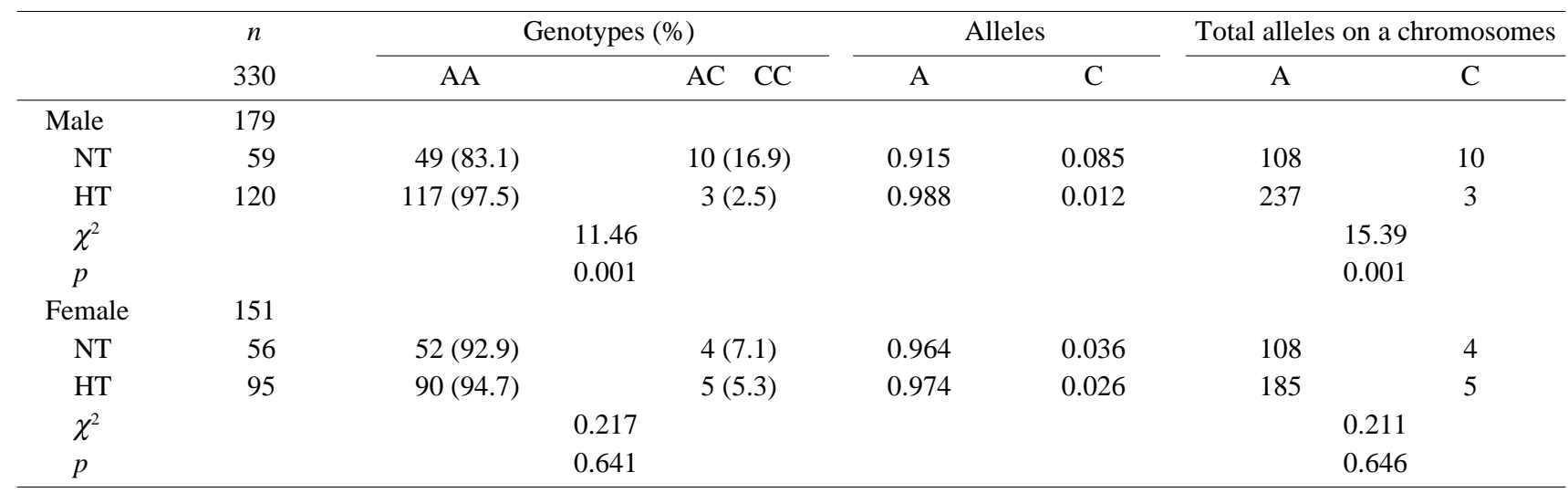

$n$, number.

the Han, Tibetan and Yi populations, respectively. There was no significant intergroup variation in frequency of the allele in normotensives $\left(\chi^{2}=4.166, p=0.125\right)$.

Frequencies of the $\mathrm{AA}$ and $\mathrm{AC}+\mathrm{CC}$ genotypes were $87.8 \%$ and $12.2 \%$ in Tibetan normotensives, and $96.3 \%$ and $3.7 \%$ in hypertensives, respectively (Table 2). Derived frequencies for the $\mathrm{A}$ and $\mathrm{C}$ alleles were 0.939 and 0.061 in Tibetan normotensives, and 0.981 and 0.019 in Tibetan hypertensives, respectively. The frequency of the AA genotype was significantly higher in Tibetan hypertensives than in normotensives $\left(\chi^{2}=8.604, p=0.003\right)$. No significant difference in the $\mathrm{A} 1166 \mathrm{C}$ genotype distribution or allele frequencies between normotensives and hypertensives was found in either the Han $\left(\chi^{2}=0.534, p=0.465\right)$ or Yi populations $\left(\chi^{2}=0.849, p=0.357\right)$.

When the Tibetan subjects were divided into male and fe- male subgroups, the distribution of the A1166C genotype differed significantly between normotensive and hypertensive groups in males $\left(\chi^{2}=11.46, p=0.001\right)$, but there was no difference in females $\left(\chi^{2}=0.217, p=0.641\right)$ (Table 3 ).

For comparison, an overview of data reported from other major population groups is provided (Table 4). In Han normotensives, the frequency of the A1166 and C1166 alleles were 0.979 and 0.021 , respectively, similar to the values observed in Japanese $(8,17)$ and African $(18)$, and approximately 1.14 to 1.50 -fold those observed in Caucasians (5, 19-22).

\section{Multiple Logistic Regression Analysis of Various Risk Factors for Hypertension}

The results of the logistic regression analysis showed that 
Table 4. Ethnic/Country Allele Frequencies of AT 1 R A1166C Polymorphism

\begin{tabular}{|c|c|c|c|c|c|c|c|c|}
\hline \multirow{2}{*}{ Ethnic groups } & \multirow{2}{*}{ Countries } & \multirow{2}{*}{$n$} & \multicolumn{3}{|c|}{ Genotypes (\%) } & \multicolumn{2}{|c|}{ Alleles } & \multirow{2}{*}{ Ref. } \\
\hline & & & AA & $\mathrm{AC}$ & $\mathrm{CC}$ & A & $\mathrm{C}$ & \\
\hline African & Ghana & 47 & $45(95.7)$ & $2(4.3)$ & $0(0.0)$ & 0.979 & 0.021 & 18 \\
\hline \multirow[t]{7}{*}{ Caucasian } & Italy & 143 & $63(44.1)$ & $61(42.7)$ & $19(13.3)$ & 0.654 & 0.346 & 19 \\
\hline & Canada & 100 & $56(56.0)$ & $37(37.0)$ & $7(7.0)$ & 0.745 & 0.255 & 20 \\
\hline & France & 723 & $355(49.1)$ & $319(44.1)$ & $49(6.8)$ & 0.712 & 0.288 & 21 \\
\hline & & 298 & $221(74.2)$ & $72(24.2)$ & $5(1.7)$ & 0.862 & 0.138 & 5 \\
\hline & Germany & 147 & $75(51.0)$ & $61(41.5)$ & $11(7.5)$ & 0.718 & 0.282 & 22 \\
\hline & & 172 & $81(47.1)$ & $76(44.2)$ & $15(8.7)$ & 0.692 & 0.308 & 7 \\
\hline & Australia & 84 & $39(46.4)$ & $42(50.0)$ & $3(3.6)$ & 0.714 & 0.286 & 15 \\
\hline \multirow[t]{2}{*}{ Japanese } & Japan & 631 & $525(83.2)$ & $103(16.3)$ & $3(0.5)$ & 0.913 & 0.087 & 17 \\
\hline & Japan & 215 & $172(80.0)$ & $40(18.6)$ & $3(1.4)$ & 0.893 & 0.107 & 8 \\
\hline \multirow[t]{4}{*}{ Chinese } & Hong Kong, China & 174 & $152(87.4)$ & $21(12.1)$ & $1(0.5)$ & 0.934 & 0.066 & 16 \\
\hline & Beijing, China & 72 & $69(95.8)$ & $3(4.2)$ & $0(0.0)$ & 0.979 & 0.021 & present study \\
\hline & Tibetan, China & 115 & $101(87.8)$ & $14(12.2)$ & $0(0.0)$ & 0.939 & 0.061 & present study \\
\hline & Yi, China & 115 & $107(93.0)$ & $8(7.0)$ & $0(0.0)$ & 0.965 & 0.035 & present study \\
\hline
\end{tabular}

$n$, number.

Table 5. Adjusted Odds Ratio of Essential Hypertension by Multivariate Logistic Regression

\begin{tabular}{lcccc}
\hline Variables & $\beta$ & Odds ratio & $95 \%$ CI & $p$ \\
\hline $\begin{array}{l}\text { Han (329) } \\
\quad \text { BMI }\end{array}$ & 0.52 & 1.67 & $1.42-1.97$ & 0.0001 \\
$\begin{array}{l}\text { Tibetan (male, 179) } \\
\quad \text { AA genotype }\end{array}$ & 2.06 & 7.87 & $1.98-31.35$ & 0.0034 \\
$\quad$ Age & 0.07 & 1.07 & $1.05-1.09$ & 0.0001 \\
Yi (male, 179) & & & & \\
$\quad$ Age & 0.09 & 1.10 & $1.05-1.15$ & 0.0001 \\
$\quad$ BMI & 0.36 & 1.44 & $1.27-1.63$ & 0.0001 \\
\hline
\end{tabular}

CI, confidence interval.

BMI in the Han and Yi populations $(p=0.0001)$, age in the Tibetan and Yi populations $(p=0.0001)$, and AA genotype in Tibetan male subjects $(p=0.0034)$ all were independent risk factors for hypertension (Table 5).

Further analysis indicated that the difference in the distribution of genotypes between Tibetan hypertensives and normotensives could only be found in males with an odds ratio of 7.87 and $95 \%$ CI of 1.98 to 31.35 for AA genotype $v s$. $\mathrm{AC}+\mathrm{CC}$ genotype $p=0.0034$, while the difference in females was not significant (data not shown). These findings suggested that the increased risk of hypertension in the Tibetan population associated with A1166 allele was specific in males.

\section{Relationship between Genotypes and Blood Pressure}

Blood pressure levels in the three populations, adjusted for age, BMI and sex, are presented in Table 6 for each genotype. No significant association between the A1166C geno- type distribution and SBP or DBP was found in either the Han or Yi populations. However, DBP levels were significantly higher in Tibetan male subjects with the AA than in those with the AC + CC genotype $(p=0.0040)$.

\section{Discussion}

Identification of genes involved in the development of essential hypertension is still a major challenge $(23-26)$. The prevalence of hypertension in China increased from $7.7 \%$ in 1980 to more than $11.8 \%$ in 1991 (10). In the present report, we included a sample of the majority Han population, which accounts for approximately $92 \%$ of the population of China, as well as samples of two minority populations, the Tibetan and Yi. These three genetically distinct populations with different prevalence rates of essential hypertension provided an excellent opportunity to study genetic factors that contribute to the pathogenesis of essential hypertension.

In our study, we found that although the frequencies of the $\mathrm{AA}$ genotype and $\mathrm{A}$ allele of the $\mathrm{AT}_{1} \mathrm{R}$ gene tended to be lower in Tibetan normotensives than in Han normotensives, the distribution of the genotype and allele did not differ significantly between Tibetan and Han. The frequency of the A1166 allele in Han normotensive was 0.979 , significantly higher than that in Caucasian populations $(5,19-22)$. Furthermore, we believe that the A1166 allele may be a predisposing factor for essential hypertension in Tibetan males but not in Han or Yi populations.

The differences in allele frequency among different ethnic groups were larger than those between hypertensive and normotensive subjects within the same ethnic group. This observation, coupled with the high allele frequency of 0.913 reported in the Japanese population (17) and that of 0.979 reported in Africans (18), led to the hypothesis that large 
Table 6. Comparison of Blood Pressure Measurements According to A1166C Genotypes

\begin{tabular}{|c|c|c|c|c|c|c|c|c|}
\hline & & \multirow{2}{*}{$\begin{array}{c}n \\
748\end{array}$} & \multicolumn{3}{|c|}{ Systolic blood pressure } & \multicolumn{3}{|c|}{ Diastolic blood pressure } \\
\hline & & & AA & $\mathrm{AC}+\mathrm{CC}$ & $p^{*}$ & AA & $\mathrm{AC}+\mathrm{CC}$ & $p^{*}$ \\
\hline \multirow[t]{2}{*}{ Han } & Male & 130 & $142.6 \pm 2.0$ & $151.8 \pm 8.4$ & 0.2900 & $94.3 \pm 1.2$ & $96.6 \pm 5.0$ & 0.5290 \\
\hline & Female & 109 & $153.0 \pm 2.3$ & $158.5 \pm 8.8$ & 0.5409 & $95.9 \pm 1.6$ & $95.5 \pm 6.0$ & 0.9591 \\
\hline \multirow[t]{2}{*}{ Tibetan } & Male & 176 & $142.3 \pm 2.2$ & $127.1 \pm 7.7$ & 0.0570 & $94.6 \pm 1.2$ & $81.6 \pm 4.3$ & 0.0040 \\
\hline & Female & 154 & $148.3 \pm 2.7$ & $146.1 \pm 10.7$ & 0.8395 & $96.1 \pm 1.4$ & $94.1 \pm 5.8$ & 0.7455 \\
\hline Yi & Male & 179 & $129.3 \pm 1.7$ & $128.6 \pm 5.8$ & 0.9067 & $84.2 \pm 1.2$ & $82.1 \pm 3.8$ & 0.5950 \\
\hline
\end{tabular}

$n$, number. ${ }^{*} p$ values were estimated by ANCOVA adjusted for age, sex and BMI.

differences in allele frequencies among ethnic groups may be important for essential hypertension.

No evidence for an association between A1166C polymorphism and essential hypertension was found in either the Han or Yi populations. The high frequency of the A1166 allele makes it impossible that this variant will be useful as a risk marker for hypertension either within the Han or Yi populations. In Tibetan males, however, the A1166 allele was significantly more frequent in hypertensives than in normotensives. In this case, our estimate differed from previously reported results $(5,7,8,15)$. The discrepancy among these studies may be due to ethnic differences. Our study showed that Tibetan male subjects with the AA genotype had higher DBP than those without it, which is consistent with the result in hypertensive subjects by Castellano et al. (19). Our results can be explained in either of two ways. First, it is possible that androgens could increase sodium reabsorption via angiotensin II-mediated increases in aldosterone (27, 28). Second, A1166C polymorphism itself does not seem to be functional, but it may be in linkage disequilibrium with an unknown genetic variant in an important functional region of the $\mathrm{AT}_{1} \mathrm{R}$ gene in the Tibetan male population. We have recently described significant association of essential hypertension with microsatellite alleles located in the $3^{\prime}$ end of the $\mathrm{AT}_{1} \mathrm{R}$ gene, insertion/deletion polymorphism in the angiotensin converting enzyme gene and M235T polymorphism in the angiotensinogen gene in the Han population $(29,30)$. An association was recently reported between A - 6G variant of the angiotensinogen gene and essential hypertension in the Han, Tibetan and Yi Populations (31). Williams et al. (18) suggested that, in terms of causing hypertension, combinations of alleles at a variety of candidate loci might be more important than the variants found at any single locus. We are currently engaged in investigating gene-gene interactions among the renin-angiotensin system gene polymorphisms.

In conclusion, the A1166 allele of the $\mathrm{AT}_{1} \mathrm{R}$ gene is very common in the Han, Tibetan and Yi populations in China, with a frequency approximately 1.35 -fold higher than that in Caucasians. The A1166 allele of the $\mathrm{AT}_{1} \mathrm{R}$ gene may be a predisposing factor in the development of essential hypertension in Tibetan males, but A1166C polymorphism does not appear to be involved in the pathogenesis of essential hyper- tension in either the Han or Yi populations.

\section{Acknowledgements}

We are grateful to Dr. Arkady Mak for her help in preparing this English manuscript.

\section{References}

1. Inagami T, Guo DF, Kitami Y: Molecular biology of angiotensin II receptors: an overview. J Hypertens 1994; 12 (Suppl 10): S83-S84.

2. Takayanagi R, Ohnaka K, Sakai Y, et al: Molecular cloning, sequence analysis and expression of a cDNA encoding human type 1 angiotensin II receptor. Biochem Biophys Res Commun 1992; 183: 910-916.

3. Weir MR, Henrich W: Theoretical basis and clinical evidence for differential effects of angiotensin-converting enzyme inhibitors and angiotensin II receptor subtype 1 blockers. Curr Opin Nephrol Hypertens 2000; 9: 403-411.

4. Perola M, Kainulainen K, Pajukanta P, et al: Genome-wide scan of predisposing loci for increased diastolic blood pressure in Finnish siblings. J Hypertens 2000; 18 : 1579-1585.

5. Bonnardeaux A, Davies E, Jeunemaitre X, et al: Angiotensin II type 1 receptor gene polymorphisms in human essential hypertension. Hypertension 1994; 24: 63-69.

6. Kainulainen K, Perola M, Terwilliger J, et al: Evidence for involvement of the type 1 angiotensin II receptor locus in essential hypertension. Hypertension 1999; 33: 844-849.

7. Schmidt S, Beige J, Maria W-F, et al: A polymorphism in the gene for the angiotensin II type 1 receptor is not associated with hypertension. J Hypertens 1997; 15: 1385-1388.

8. Takami S, Katsuya T, Raguki H, et al: Angiotensin II type 1 receptor gene polymorphism is associated with increase of left ventricular mass but not with hypertension. Am J Hypertens 1998; 11: 316-321.

9. Paillard F, Chansel D, Brand E, et al: Genotype-phenotype relationships for the renin-angiotensin-aldosterone system in a normal population. Hypertension 1999; 34: 423-429.

10. Fuentes R, Ilmaniemi N, Laurikainen E, et al: Hypertension in developing economies: a review of population-based studies carried out from 1980 to 1998. J Hypertens 2000; 18: 521-529.

11. Liu LS: Hypertension studies in China. Clin Exp Hypertens 1993; 15: 1015-1024.

12. Kawamura H, Jumabay M, Mitsubayashi H, et al: 24-hour 
blood pressure in Uygur, Kazakh and Han elderly subjects in China. Hypertens Res 2000; 23: 177-185.

13. Liu LS: Hypertension studies in China. Clin Exp Hypertens 1989; 11A: 859-868.

14. Chu JY, Huang W, Kuang SQ, et al: Genetic relationship of population in China. Proc Natl Acad Sci USA 1998; 95: 11763-11768.

15. Wang WYS, Zee RYL, Morris BJ: Association of angiotensin II type 1 receptor gene polymorphism with essential hypertension. Clin Genet 1997; 51: 31-34.

16. Thomas GN, Young RP, Tomlinson B, et al: Reninagiotensin-aldosterone system gene polymorphisms and hypertension in Hong Kong Chinese. Clin Exp Hypertens 2000; 22: 87-97.

17. Kato N, Sugiyama $\mathrm{T}$, Morita $\mathrm{H}$, et al: Comprehensive analysis of the rennin-angiotensin gene polymorphism with relation to hypertension in the Japanese. J Hypertens 2000; 18: $1025-1032$.

18. Williams SM, Addy JH, Phillips JA: Combinations of variations in multiple genes are associated with hypertension. Hypertension 2000; 36: 2-6.

19. Castellano M, Muiesan ML, Beschi M, et al: Angiotensin II type 1 receptor A/C ${ }^{1166}$ polymorphism. Hypertension 1996; 28: 1076-1080.

20. Pei Y, Scholey J, Thai K, et al: Association of angiotensinogen gene T235 variant with progression of immunoglobin a nephropathy in Caucasians patients. J Clin Invest 1997; 100: 814-820.

21. Tiret L, Bonnardeaux A, Poirier O, et al: Synergistic effects of angiotensin-converting enzyme and angiotensin II type 1 receptor gene polymorphisms on risk of myocardial infarction. Lancet 1994; 344: 910-913.

22. Erdmann J, Riedel K, Rohde K, et al: Characterization of polymorphisms in the promoter of the human angiotensin II type 1 (AT1) receptor gene. Ann Hum Genet 1999; 63: 369-374.

23. Niu THM, Xu XP, Cordell HJ, et al: Linkage analysis of candidate genes and gene-gene interactions in Chinese hypertensive sib pairs. Hypertension 1999; 33: 1332-1337.

24. Corvol P, Persu A, Gimenez-Roqueplo A-P, et al: Seven lessons from two candidate genes in human essential hypertension. Hypertension 1999; 33: 1324-1331.

25. Katsuya T, Sato N, Asai T, et al: Association of polymorphism in the promoter region of the apolipoprotein $\mathrm{E}$ gene with diastolic blood pressure in normotensive Japanese. Hypertens Res 2000; 23: 271-275.

26. Kuriyama S, Tomonari H, Tokudome G, et al: Association of angiotensinogen gene polymorphism with erythropoietin-induced hypertension: a preliminary report. Hypertens Res 2001; 24: 501-505.

27. Bachmann J, Feldmer M, Ganten U, et al: Sexual dimorphism of blood pressure: possible role of the renin-angiotensin system. J Steroid Biochem Mol Biol 1991; 40: 511-515.

28. Reckelhoff JF: Gender differences in the regulation of blood pressure. Hypertension 2001; 37: 1199-1208.

29. Liu Y, Qiu CC, Zhou WY, et al: Gene polymorphisms of the renin-angiotensin system in essential hypertension. Chin Med J 1999; 112: 115-120.

30. Liu Y, Zhou WY, Hou SQ, et al: Association analysis of polymorphisms of ACE gene and AGT gene with essential hypertension in Chinese Han's population. Chin Med Sci J 1998; 13: 71-76.

31. Liu YW, Qin WJ, Hou SQ, et al: A - 6G variant of the angiotensinogen gene and essential hypertension in Han, Tibetan, and Yi populations. Hypertens Res 2001; 24: 159-163. 